\title{
Migration, Education, and Externalities
}

\author{
Rahul Gupta Choudhury \\ IFIM Business School; Electronics City; Bangalore; India.
}

\begin{abstract}
Migration is an age-old phenomenon across the world. It has been seen that people migrate to improve their lot. It is a logical decision based on cost-benefit analysis. This paper goes into the details of motivation of the phenomenon called migration. For a large part of the discussion, the references and data/information has been drawn from the European Union. The main reasons are that data is easily available, migration to developed European countries have been going on for quite some time, and the phenomenon has generated a fair lot of debate and politics in the recent years. This paper attempts to look at it from a scholarly point of view, particularly emphasizing on the relationship between returns to migration and education. The paper has also gone one step ahead and analyzed the situation and attempts to explain from the point of view of the economic phenomenon of 'externalities'. The analysis throws up some interesting observations which will hold true irrespective of the geographical incidence of the phenomenon. Symmetric and easily available information on labor markets will help in better match of demand and supply of skills, and thus help the educated individuals to get better returns on their investment in education - a higher return on human capital.

Keywords: Migration, Education, Externalities, Human Capital, European Union
\end{abstract}

\section{Introduction}

Migration is a phenomenon which generates a lot of discussion and debate, both in the academia as well as in the real world of political administration. Though it is a real issue of incomparable dimension in the human existence, including all civilizations, the subject has not seen much research in the academia. It is as if the migrants take their own decision and hence should be left to themselves to sort out their problems - the world turns a blind eye towards them. This paper is about understanding and appreciating the role education plays in the life of the migrants. In economic terms, there is a study on the returns that immigrants obtain from their investments in education, and whether there is differential return between locals and immigrants in the host country. Attempt has been made to identify factors which are responsible in determining the returns on the investments in human capital. The concept of externalities has been brought in to understand whether the outcomes of immigration are socially optimal. It is now accepted that people act collectively in order to maximize potential income and minimize risks associated with labor-market failure and other market imperfections. Structural inflation and Motivational constraints force the migrants to work at the lower end of the job hierarchy in the host country. Education, in the long run, may help the migrants to escape this downward spiral - and many unheard of factors like educationlevel of the family members of themigrant, plays an important role of fulfilling his objective of escaping the poverty and poor working conditions of his country of origin.Mincer has established that earning potential is a function of schooling and years of work experience.Migrants try to maximize household income and/or are flexible in distribution of household chores. So, international women migrants are better off. However, we must remember that women (or, wives) sacrifice the most, most often in favor of the family (or, their husbands). In the end, countries and societies have realized that migration leads to integration of ideas and institutions and also generates far more cultural evolution today than does conquest. This particularly holds true if the migrants possess education, especially till the tertiary level.

\section{Externalities}

In Economics, Externality is a transaction spillover - it is a cost or benefit not transmitted through prices, that is incurred by a party who do not agree to the action causing the cost or benefit. Prices in a competitive market do not reflect the full cost or benefits of producing or consuming a product or service. In Welfare Economics, existence of externalities results in outcomes that are not socially optimal. Those who suffer from external costs do so involuntarily, while those who enjoy external benefits do so at no cost. 


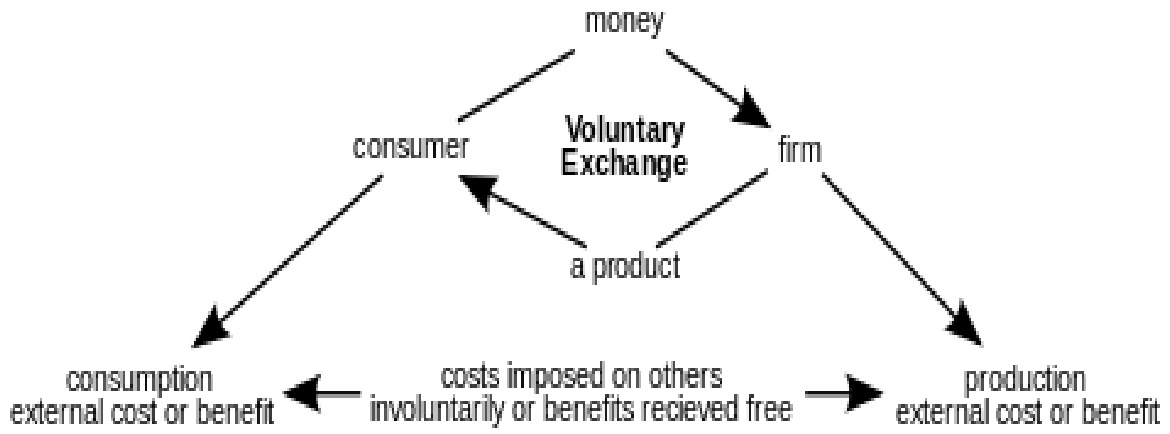

Negative Externality: is the action of a product on consumers that imposes a negative side-effect on a third party; it is "social cost". Examples are: Air pollution, anthropogenic climate change - greenhouse gas, Systemic risk - banking, harvesting - overfishing, Business - pension funds - moral hazard, pecuniary externalities.

Positive Externalities: Increased education - greater economic productivity, lower unemployment rate, greater household mobility and higher rates of political participation. Examples are: Public organization prevention of infectious diseases, Network externality - tipping points, Knowledge spillover of inventions and information.

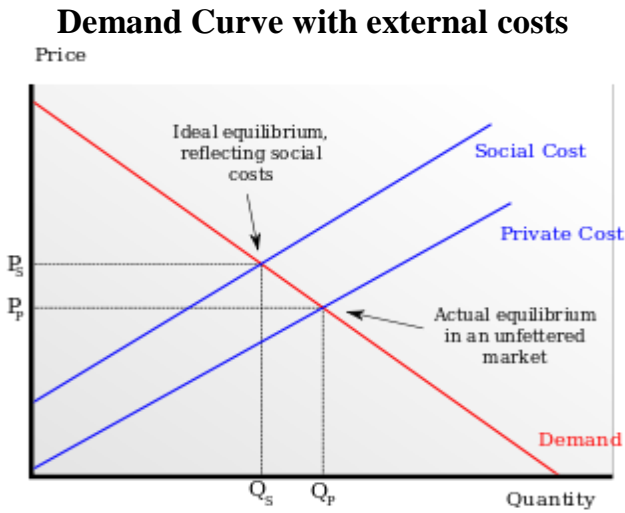

If social costs are not accounted for price is too low to cover all costs and hence quantity produced is unnecessarily high (because the producers of the good and their customers are essentially underpaying the total, real factors of production). Marginal social benefit should be equal to marginal social cost. So, 'free market' is inefficient.

When the market does not account for external social benefits of a good both the price for the good and the quantity produced are lower than the market could bear. Examples:

Public good has beneficial externalities for all. Problem of societal communication and coordination to balance benefits and costs. In case of Merit good, the government steps in with a collective solution.

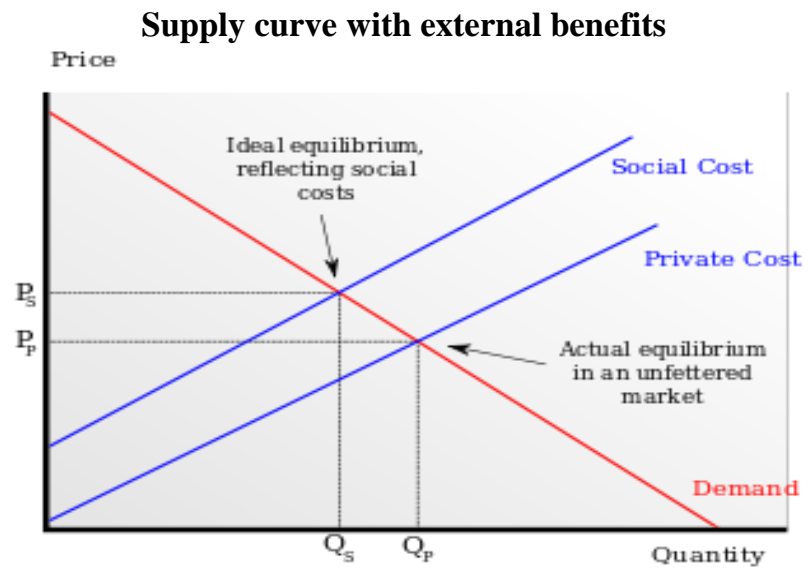


Theories of Migration:It is triggered by push-pull mechanisms, where push lower the returns on one's human capital investment in the home country - such as, high unemployment or low wages. Pull - increase the returns on investments in human capital in the receiving country - such as, high labor demand, high wages, and better working conditions.

According to Neoclassical economic theory, at the Macro level, migration occurs due to the differences in labor supply and demand. Countries with large volume of labor relative to capital have a low-equilibrium market wage; and vice-versa. People from low-wage countries move to high-wage countries. Capital flows in the opposite direction. At the Micro level, emigrant is a calculated and rational actor. He chooses to migrate in order to maximize his benefit.

Migration is an investment in human capital. Against higher expected returns on own skills, migration cost includes: material cost of travelling, cost of maintenance in the host country while looking for a job, psychological cost of cutting ties with social network in the home country, cost (effort) in learning a new language and culture, psychological cost of creating a new social network, and the difficulties experienced in adapting to the new situation. The expected benefits are higher expected wage multiplied by expected probability of beingemployed, discounted over the temporal horizon of migration. The individual migrates when benefits are larger than costs.

New economics of migration: The new theory, which started in the 1980's, postulates that migration decisions are not taken by individuals - but, by households and families. People actcollectively in order to maximizepotential income and minimize risks associated with labor-market failure and other market imperfections. Migration generates cash flow to finance small investments in family operations, where undeveloped credit markets cause credit constraints. Migration serves as insurance for bad crops, where insurance markets are not well-developed. Households try to diversify their source of wages, as Income is a positional good. In a given geographical area, local income rankings are altered as remittances begin to flow from the emigrant. This starts of a sort of competition among families/households.

So, in opposition to neoclassical perspective, remittances spur local economic growth. As a result, international migration flow, instead of reducing, might intensify.

Now, let us have a look at Positional Goods. Products and services whose value is mostly (if not exclusively) a function of their ranking in desirability, compared to substitutes. They create externalities that might boost one's social status relative to others. There is a phenomenon of relative deprivation - a perception that one's position in a stratification system is worse than the position of others with whom one compares oneself. This phenomenon can also play out its effect at regional level.

Dual Segmented Labor Force Theory:Migration stems from an intrinsic demand of modern societies - need foreign labor because of an economic dualism created by labor and capital. In the Primary sector, capital is expensive and hence capitalists employ stable and skilled quantity of labor to run the capital at normal capacity. In the secondary sector, economy expands and additional demand materializes, and capitalists use additional labor. However, in the secondary sector, jobs are essentially unstable and do not require high stock of educational capital. Salary levels are low in this sector, and there is hardly any scope of promotion. This secondary sector is normally occupied by immigrants. There are two factors behind this phenomenon: structural inflation and motivational constraints. We need to understand this at a more detailed level.

Structural Inflation:Jobs represent one's position in society and one's personal value. It confers status and prestige to the individual. There exists a correlation between wages, occupational status, and jobs. Also, there is a hierarchy of jobs and wages which constrains employers' ability to manipulate wages. So, wages remains a function of changes in labor demand and supply. Wages adhere to the hierarchy of prestige in the form of collective agreements, bureaucratic career rules, company job classifications, years of service rules, AND social expectations and norms. Even though there is a shortage of labor at the low end of wage distribution, wages cannot be raised as that will put the relative position of jobs and pay in disarray. If at all, wages has to be increased throughout the hierarchy.

Motivational Constraints:It has now been proved that workers do not work for pay alone. One of the major motivations of work is to accumulate status. At the bottom of the job hierarchy, there are motivational problems because of low status of the job and minimal scope of upward mobility. So, the problem is structural as all hierarchy will have to have a bottom. As employers need workers, circumstances prevail in a way that the only important aspect of the job becomes the wages, which is a means to earn money. Migrants, especially in the early phase of their experience, fit this description very well. They have no other option but to concentrate on financial gain, which confers on them a new status in their home country, but not in their destination land. 
Andres Rodriguez-Pose and Vassilis Tselios (Feb. 2010) [1\} studied extensively on labor, household and regional economics. They also studied, simultaneously, the economic and pecuniary returns to migration. An important aspect of the study was to establish the determinants of migrants' wages in comparison to that of nonmigrants. Literature survey has shown that individualdifferences in education, gender, employment, and other observable characteristics are relevant in determining earnings of both migrants as well as non-migrants. What wereoverlooked so far in literature were the geographical factors, which means, in other words, place- based endowments and conditions. Some places are welcoming to migrants, while others are migrant averse. The authors' study focused on whether and how place-based externalities (regional and interregional) matter in determining the pecuniary returns to migration.

The data for their study was obtained from European Community Household Panel (ECHP). The aim was twofold. The first was to establish that individual pecuniary returns to schooling vary. The control was on series of individual background variables, such as occupational and employment status and health - between migrants and locals and between two migrant groups, intranational and international migrants. The second aim was to establish that household and geographical wage and educational externalities affect the individual earnings of migrants and locals in different ways. Other factors that may influence the earning potential of migrants are number of years a migrant has been living in any particular region or the level of development of the country of origin. The authors could establish that differences in earnings between migrants and nonmigrants across regions in $\mathrm{EU}$ are results of:

1) Educational attainment of the individual

2) Educational attainment and wage of other members of the household (household externalities)

3) Educational endowment and wage level of the region where the individual lives (regional externalities)

4) Educational endowments and wage level of the neighboring regions (interregional externalities).

Theoretical Considerations: migration and externalities: -The role of individual returns to schooling is dependent on migration and individual characteristics. The main factor explaining differences in earnings among individuals is education.Education is thought of as investment of current resources in exchange for future returns. Higher the level of education of an individual, the higher the expected economic returns. Education enhances the innate skills of an individual, increases social and job opportunities, and his/her productivity. It also acts as a 'label' or 'signal' in the labor market. Individuals with similar levels of qualifications and in similar jobs should expect similar wages. However, a series of factors alters this expected relationship.

On the positive side for migrants, the authors found that the migrants possess higher level of innate ability and are more receptive to economic incentives. They are more dynamic and entrepreneurial as they try to maximize the value of their lifetime utility. They weigh benefits against financial and psychological costs, thus, moving to areas yielding the highest potential individual economic returns. One of the personal traits of migrants is that they factor-in short term initial loss in earnings.

The negative side of migrants includes lack of complete information or biased information. There are legal barriers as well as lack or deficient knowledge of language. Valuation of the migrants' skills is a deterrent, especially for partners of initial migrants, after family reunification. It has been noticed that international migrants tend to be much more affected.

The migrants have to balance between the positive and negative factors - but, in most cases, the outcome is unclear.

Household background is a powerful determinant of earnings, while household externalities, in principle, are likely to affect locals and migrants in a similar way. Decisions to migrate are also determined by characteristics of other members of the household (also known as 'tied' movers). Wages fall at least in the shortrun, while wives sacrifice to support their husbands. It has been found that negative household externalities are more likely to affect international than intranational migrants.

The major observations of the study are:

- Earnings potential of any individual depends on a series of place-based (regional and interregional) conditions.

- Income of equally educated individuals varies significantly from one region to another.

- (Inter)regional wage and education spillovers play a prominent role in theories of economic development

- Increase in productivity - knowledge - leak from one worker to another and from one region to another

- Educational externalities raises productivity and economic-sharing and exchange

- Pecuniary externalities also raise productivity through prices

- Higher educational endowment and economic development of a region leads to increase in productivity through interaction with others within the region

- Knowledge and skills have big economic payoff. People will respond to the incentive by accumulating knowledge. 
- There is a greater incentive to get educated in regions with a higher average level of education

- Productivity gains from geographic concentration remained inconclusive when estimating averageschooling externalities (example of US cities).

- Interregional externalities contribute significantly to regional economic development

- Non-monetary and monetary flows are stronger in regions which are geographically close, which may be termed as homogeneous regions. They share markets for labor and goods and have similar capital and managerial talent.

- Externalities result in concentration of firms in macro-areas spanning several regions.

- Diffusion of technology is stronger in regions with same socioeconomic characteristics

- Main cause of migration is wage differentials between areas

- Differences in regional unemployment levels play a similar role

- Geographical externalities have detrimental effects on migrants

- Invisible barriers prevents migrants from fulfilling full educational potential, which affects the labor market

- International immigrants are more likely to experience these barriers than intranational ones.

Econometric specification, data and variables: -the study aims to investigate:

- Whether there are differences in economic returns to education among different types of migrants and locals across regions in EU

- Whether household and geographical externalities play a role in the presence or absence of such differences Not only individual variables, but also household-level, regional-level, and supra-regional-level variables as explanatory variables, were considered in the study.In Mincerian specification, we add:

1) Educational attainment of the individual

2) Educational attainment and wage of other members of the household

3) Educational endowment and per capita wage of the region

4) Educational endowment and per capita wage of neighboring regions

\section{Mincerian Specification:}

Jacob Mincer, father of modern Labor Economics - Chicago School of Economics, and Nobel Laureate Gary Becker developed the empirical foundations [5] of human capital theory [7]. Mincerian equations model wages as a function of human capital in statistical estimation. They established the link between wages (observed) and the quantity of skills owned by an individual (unobserved) in a competitive labor market. Their proposed equation was:

$\mathrm{W}=\mathrm{P} * \mathrm{H} \quad$ (converted to $\log )$

Mincer (1974): The Mincerian Wage Regression

They found that in US additional years of schooling is associated with $7 \%$ to $10 \%$ higher earnings. Thus, the final equation became:

$\ln \mathbf{Y}=\mathbf{S X}+\mathbf{W X}+\mathbf{W}^{\wedge} \mathbf{2 X} ;$ where

$\ln \mathrm{Y}$ - wages or log earnings,

$\mathrm{S}$ - years of schooling,

$\mathrm{W}$ - years of work experience.

Three categories of workers were considered: locals, intranational migrants and international migrants. Obviously, characteristics of the categories differ significantly [8]. Controls include a series of individual, household, regional and interregional variables - aimed at minimizing selection bias. Two factors were included: a)number of years a migrant has lived in any particular region and b) GDP per capita, as an indication of the region of origin of international migrants.

In the study the dataset covered 321,026 individuals living in 80 regions and 12 European countries forthe period 1994-2001. Real wages were measured instead of nominal ones. In the dataset, 72.69\% was locals, $21.63 \%$ intranational, and $5.68 \%$ international immigrants. Among the international immigrants, $86.48 \%$ were normally working individuals, $5.24 \%$ and $8.14 \%$ was unemployed and inactive [6]. The sample displays the following:

- Migrants have higher wages and higher average educational attainment

- Intranational migrants are superior to international migrants

- Wage and educational attainment of other members of household are higher for migrants than locals

- Per capita wage and educational endowment of regions with high concentration of migrants are higher

- Per capita wage of neighboring regions is higher in regions without a high concentration of migrants

- By and large, immigrants have a higher level of education than locals, which may be an important factor in determining their earnings.

- Migrants have a greater work experience than locals 
- Men dominate the sample

The result of the regression analysis (obtained from the Mincerian equation) is as follows:

- Pecuniary returns to education is marginally higher for migrants

- These disappear when externalities or other controls are included

- Marginal difference in economic returns to education in favor of international migrants

- Intranational migrants have $10 \%$ higher returns

- So, no discrimination against migrants in European labor market

- There is division of tasks in the households based on gender

- Women sacrifice career prospects to fulfill other tasks and this is applicable to all categories

- Negative effect of household wage externalities is somewhat lower for international migrants

- As a result, there is less relevance of 'tied' movers concept

- Migrants try to maximize household income and/or flexible in distribution of household chores

- So, international women migrants are better off

- Household education externalities are positive and are highest for intranational migrants

- Women tend to sacrifice their career prospects in local and international migrant category

- Wage externalities are more relevant than education externalities

- Regions with high average earnings will give better returns to individuals with same educational characteristics

- International migrants benefit more from regional wage externalities

- With interregional externalities, coefficient for intraregional immigrants is highest

- International migrants are relatively swiftly integrated in the labor market

- Intranational migrants are economically rewarded depending on the number of years of living in the region

- Level of development of the country of origin does not affect wages of international migrants

- Men tend to earn significantly more than women

- There is a non-linear relationship between experience and wages

Sensitivity:

- Over education makes a difference for earnings

- Industrial workers earn higher wages than service workers

- Service workers earn more than agricultural workers

- Public sector employees earn more than private sector

- Legislators, senior officials and managers, professional, and technicians have highest earnings

- Agricultural and fishery workers have the lowest earnings

- Individuals with poor health have the lowest earnings

- Earnings of individuals decrease with household size

- Couples without children has the highest earnings, closely followed by couples with one child

- Couples with three or more young children and the elderly has the lowest earnings

- Sectorial specialization of the region matter for earnings

- Innovation matter for earnings. It is measured by total R\&D expenditure as a percentage of GDP (and not by patent applications)

- Public infrastructure has positive impact on individual earnings

- Population density has negative impact on individual earnings

In conclusion, the authors assert that, across the board, education matters for earnings. Across different categories of individuals, household and geographic externalities make a difference for earnings. Settling-in periods does not have a dent in the earnings of the migrants. Genderand experience matter for earnings and has a similar impact across categories. Contrary to expectations, there is virtually no discrimination against migrant workers inthe European labor market. Locals and migrants with similar levels of education tend to command similar wages. Gender discrimination is a more pervasive and relevant feature of the European labor market.

Richerson and Boyd (DEC 2008), in their article in Nature, observes that migration has a profound effect on how societies evolve culturally - as it is selective. People move to societies that provide a more attractive way of life, and all other things being equal, this process spreads ideas and institutions. The authors claim that this process promotes economic efficiency, social order and equality. Various processes change the distribution of cultural variants through time. Some processes act at the individual level and these individuallevel processes can stabilize a vast array of beliefs and institutions. Militarily or economically more powerful societies expand at the expense of weaker societies and hence, European ideas and institutions spread to the rest of the world. In today's world order, we see people moving from poorer or more chaotic or more unequal 
societies to richer, more orderly and more just ones. Ultimately, people move in the hope of improving their lot. The goals and aspirations may vary at an individual level, but most prefer wealth to poverty, safety and security to fear and danger, health to illness, and equality to inequality. As has been discussed earlier, migration leads to integration of ideas and institutions and also generates far more cultural evolution today than does conquest. Assimilation and adaptation are part of the migrant's life, which has started a long time ago - for example, Mongols in China and Mughals in India. The authors also assert that societies that attract immigrants tend to have ideas and institutions that cause them to be richer, less violent, and less exploitative.As examples they cite Christianity, Confucian humanism, and Hindu tolerance. So, immigrants are a more powerful engine of social change than armies.

\section{Qualitative Euro barometer}

European Commission in their aggregate report on May 2011 on Immigrant Integration makes some insightful observations. The general public and non-EU immigrants come in contact mostly in their workplace and schools. The main barrier is language and the desire to interact. There are also cultural differences, stereotyping, and lack of understanding. Genuine fear and resentment towards immigrants exist as they compete for employment opportunities or jobs. There are both positive and negative perceptions of migrants. Strong association between migrants and criminal activities exist in the region - however, mostly attributed to creation of media. However, migrants take up jobs with poor salary and poor working conditions - jobs that locals do not want to do. Migrants are mostly concentrated in healthcare, construction and domestic cleaning. The general public believes that migrants contribute only by paying taxes. There is a growing realization that migrants can contribute positively to the national culture and that they need to be integrated into society. Whether welcomed by society or not, formation of "ghettos" is a reality in most countries. The final objective of the migrants ought to be that they can speak the language, enjoy legal status, have a job and respect local cultures. They will also have equality, freedom from exploitation, and enjoy equal rights with locals. It is only when they have security and peace of mind can they plan for the future. So, there is a need for a change in the attitude of the general public. The social system is being abused as there are too many migrants and the governments are not doing enough. Migrants have to continuously struggle with hostile bureaucracy and inequality in government processes and procedures. The commission suggested some steps which would be useful to solve problems of this nature.Financial incentives could be given to companies for recruiting migrants. However, this could be contentious as it may come in the domain of positive discrimination. Similarly, efforts could be made to ensure equality in Public sector through access and recruitment. However, again this may also be contentious. Suggestion is also to organize cultural activities in schools and have accurate, unbiased, and realistic portrayal of migrants through media.

Andres Rodriguez-Pose and Montserrat Vilalta (November, 2004) [9] establishes a link between human capital and regional economic performance in the EU. They identified indicators ofeducational stock, matching ofeducational supply and labor demand, and migration (from ECHP). It is observed that economicperformance is associatedwith differences in human capital endowment. Factors such as matching of educational supply and local labor needs, job satisfaction, and migration have stronger connection to economic performance than educational stock. There is now a scholarly agreement that human capital is an important determinant of economic growth. However, there is no consensus on exact contribution of different measures and indicators of human capital to economic development and on how the passage from human capital endowment to economic growth is achieved. Decent educational stock may have little impact on local economic performance and regional disparities. Shortages or deficiencies are solved by attracting highly qualified or skilled manpower from other areas. These simplistic policieshave substantial deleterious effects. Factors which matter for economic growth are type, quality, and/or quantity of the stock of the human capital, efficiency of allocation of human capital, and allocation of educational resources.

It is common knowledge that economic wealth and development levels are not evenly distributed across the EU. Winning and catching-up regions generally enjoy a better match between educational supply and labor demand and have a greater proportion of satisfied workers (Axelsson R, Westerlund O (1998) [3]). Regions with higher initial GDP have the highest percentage of international migration. Winning regions feature a better educated stock of population, larger proportion of their population in full time education, and attract highly qualified inward migration. Winning regions manage to attract highly qualified workers (Basu K, Narayan A, Ravallion M (2001) [4]).

At the end of all this discussions, it can be said that there is significant correlation between the endowment of human capital in the European regions and their economic performance over the last few years (Acemoglu D, Angrist J (2001) [2]).Stock variables are more likely to be associated with wealth, whereas job satisfaction, matching indicators, and migration are more closely related to economic performance. It is quite evident that there is a lot of importance of education and experience in the economic potential of a region. 
Economic returns to investment in education in peripheral regions tend to be higher and more significant than those in alternative investment such as infrastructure or business support.

European Centre for the Development of Vocational Training observes that problems faced by migrant workers are that of relatively scarce endowment in social capital. In order to maximize growth potential factors of production must be free to flow to the regions/countries (but also sectors) where their returns are highest. Some labor markets have excess demand, while others exhibit excess supply. Workers should move from high unemployment areas to high vacancy area. They consider Germany which has a migration background. There are two distinct groups of foreign workers: 1) highly skilled, where international mobility is part of their careers and, 2) low skilled and skilled workers, were there is a differential in average wages. Then there is the case of Italy, where migration takes place from the Southern to the Northern region. Italy mostly loses academic personnel; Hungary \& Estonia loses medical doctors; while, for Lithuania, the loss is of academic personnel and of highly skilled civil servants. In the countries of Czech Republic, Estonia and Slovakia, there are enough highly educated workers still available in the national labor market. All countries are unanimous that all migrants move for economic reasons, such as better wages, better jobs and better working conditions. The most important driver for semi-skilled and skilled workers are high wage differential. Employed workers migrate more often because of low wages and poor living conditions in their home countries, rather than better prospective wages abroad.

\section{Problems faced by Migrants}

There is a systematic underutilization of immigrant worker skills as they are mostly overqualified for the job they do in the host country. Information problems pervade the labor market: (geographic) search frictions and selection frictions (and stereotyping). Search frictions happen when firms do not exactly know how to locate prospective workers with desirable characteristics, and workers have difficulties in locating vacancies. Selection frictions occur when prospective employers lack the cultural categories needed to assess worker productivity. Information about workers educational titles or past employment records are difficult to evaluate. Hence, hiring managers may end up relying on stereotypes to assess productivity. Foreign workers face discrimination as they are perceived to be different: out-groups and in-groups. Foreign workers have an impact on the labor market. They have minor negative impact on wages and jobs of native workers, but, larger impact on the older waves of immigrants (may be substitutes). Foreign workers tend to be absorbed in the labor market when final demand is strong. It has been noticed that in Nordic countries, the economic impact of migration is positive. Also, migration has sustained internal demand contributing to economic growth. Willingness of migrants to take up low qualified jobs has slowed down wage dynamics at the low end of the wage distribution. This downward pressure on wages contributed to low inflation, even in the face of a strong aggregate demand. Foreign workers lose their jobs more easily and once unemployed, find it more difficult to find a new job (compared to native workers). Sweden has a reverse perspective where foreign workers are characterized by high employment rates and are net contributors to the welfare state.

There are two tables given below. The first table gives the tertiary education levels in the countries in European Union. The second table gives the unemployment rate in the same countries in the EU. It is observed that there is not much of a difference in the tertiary education levels of 'total population' and 'foreign-born population'. However, among the foreign-born, EU born seems to be slightly better educated than non-EU born. 


\section{Migration, Education, and Externalities}

Table 11a. Share of population with tertiary, secondary and primary or less than primary education (highest educational attainment) by groups of country of birth, age groups and sex, $2010(\%)$

A. TOTAL / TERTIARY EDUCATION

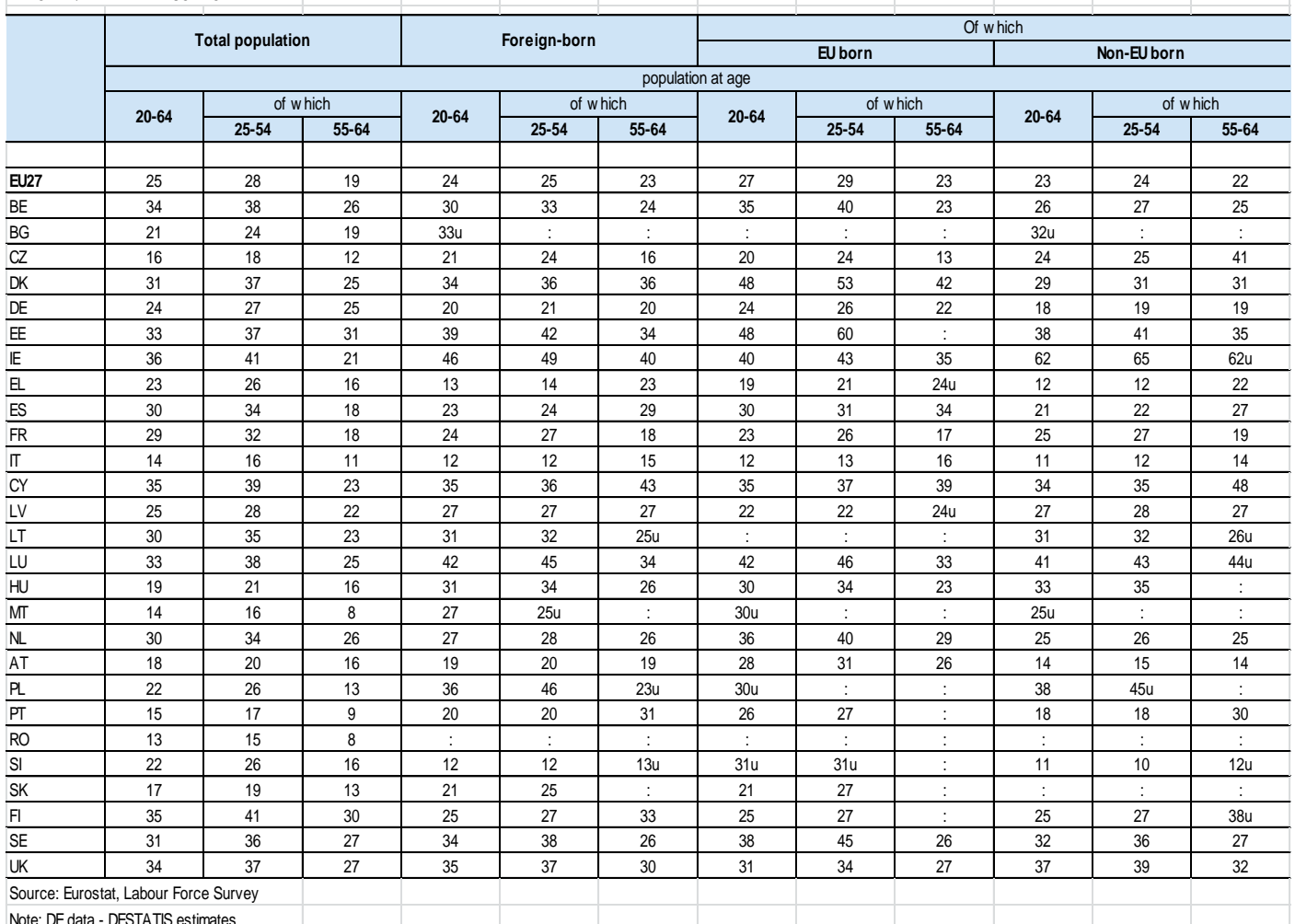

Overall, there is no significant difference between locals and migrants in terms of education, in the EU. There does not seem to be any pattern either.

Table 3a. Unemployment rate by groups of country of birth, age groups and sex, 2010 (\%)

A. TOTAL

\begin{tabular}{|c|c|c|c|c|c|c|c|c|c|c|c|c|}
\hline & \multirow{2}{*}{\multicolumn{3}{|c|}{ Total population }} & \multirow{2}{*}{\multicolumn{3}{|c|}{ Foreign-born }} & \multicolumn{6}{|c|}{ Of which } \\
\hline & & & & & & & \multicolumn{3}{|c|}{ EUborn } & \multicolumn{3}{|c|}{ Non-EU born } \\
\hline & \multicolumn{12}{|c|}{ population at age } \\
\hline & \multirow{2}{*}{$20-64$} & \multicolumn{2}{|c|}{ of which } & \multirow{2}{*}{$20-64$} & \multicolumn{2}{|c|}{ of which } & \multirow{2}{*}{$20-64$} & \multicolumn{2}{|c|}{ of which } & \multirow{2}{*}{$20-64$} & \multicolumn{2}{|c|}{ of which } \\
\hline & & $25-54$ & $55-64$ & & $25-54$ & $55-64$ & & $25-54$ & $55-64$ & & $25-54$ & $55-64$ \\
\hline EU27 & 9 & 9 & 7 & 14 & 14 & 13 & 11 & 10 & 9 & 16 & 16 & 15 \\
\hline $\mathrm{BE}$ & 8 & 7 & 5 & 17 & 17 & 12 & 10 & 9 & $9 u$ & 23 & 23 & $18 u$ \\
\hline$B G$ & 10 & 9 & 9 & $:$ & $:$ & $:$ & $:$ & $:$ & $:$ & $:$ & $:$ & $:$ \\
\hline $\mathrm{CZ}$ & 7 & 6 & 6 & 7 & 6 & 15 & 8 & 6 & 16 & 6 & 6 & $:$ \\
\hline DK & 7 & 6 & 6 & 13 & 13 & $11 u$ & 9 & 8 & $:$ & 15 & 15 & $:$ \\
\hline DE & 7 & 7 & 8 & 12 & 11 & 14 & 8 & 8 & 10 & 13 & 13 & 17 \\
\hline EE & 17 & 15 & 16 & 23 & 23 & 22 & $:$ & $:$ & $:$ & 23 & 23 & 22 \\
\hline $\mathrm{E}$ & 13 & 13 & 9 & 16 & 16 & $15 u$ & 17 & 17 & $:$ & 15 & 15 & $:$ \\
\hline EL & 12 & 12 & 6 & 16 & 15 & 16 & 13 & 13 & $:$ & 16 & 15 & 18 \\
\hline ES & 19 & 19 & 14 & 28 & 27 & 30 & 25 & 24 & 24 & 29 & 28 & 31 \\
\hline FR & 9 & 8 & 7 & 15 & 14 & 11 & 8 & 7 & 6 & 17 & 17 & 13 \\
\hline$\pi$ & 8 & 8 & 4 & 11 & 10 & 7 & 11 & 10 & 6 & 11 & 11 & 8 \\
\hline CY & 6 & 5 & 5 & 8 & 7 & $:$ & 9 & 8 & $\vdots$ & 8 & 7 & $:$ \\
\hline LV & 18 & 17 & 16 & 19 & 20 & 15 & 23 & 28 & $:$ & 18 & 19 & 16 \\
\hline LT & 18 & 17 & 14 & 19 & 19 & $:$ & $:$ & $:$ & $:$ & 19 & 19 & $:$ \\
\hline LU & 4 & 4 & $:$ & 6 & 5 & $:$ & 5 & 5 & $:$ & 11 & $10 \mathrm{u}$ & $:$ \\
\hline $\mathrm{HU}$ & 11 & 10 & 8 & 7 & 6 & $:$ & 7 & $6 u$ & $:$ & $:$ & $:$ & $:$ \\
\hline MT & 6 & 6 & $:$ & $:$ & $:$ & $:$ & $:$ & $:$ & $:$ & $:$ & $:$ & $:$ \\
\hline NL & 4 & 4 & 4 & 8 & 8 & 7 & 5 & 5 & $7 u$ & 9 & 9 & 7 \\
\hline AT & 4 & 4 & 2 & 8 & 8 & $5 u$ & 6 & 6 & $:$ & 9 & 9 & : \\
\hline PL & 9 & 8 & 7 & $:$ & $:$ & $:$ & $:$ & $:$ & $:$ & $:$ & $:$ & $:$ \\
\hline PT & 11 & 11 & 9 & 15 & 14 & $:$ & 12 & 11 & $:$ & 16 & 15 & $:$ \\
\hline RO & 7 & 6 & 3 & $:$ & $:$ & $:$ & $:$ & $:$ & $:$ & $:$ & $:$ & $:$ \\
\hline SI & 7 & 7 & $4 u$ & 10 & 9 & $8 u$ & $:$ & $:$ & $:$ & 10 & 10 & $8 u$ \\
\hline SK & 14 & 13 & 10 & $:$ & $:$ & $:$ & $:$ & $:$ & $:$ & $:$ & $:$ & $:$ \\
\hline $\mathrm{Fl}$ & 8 & 7 & 7 & 16 & 15 & $:$ & 10 & $10 u$ & : & 21 & 18 & $:$ \\
\hline SE & 7 & 6 & 5 & 15 & 15 & 10 & 8 & 8 & 6 & 19 & 18 & 16 \\
\hline UK & 7 & 6 & 5 & 8 & 8 & 8 & 6 & 6 & 6 & 10 & 9 & 9 \\
\hline \multicolumn{13}{|c|}{ Source: Eurostat, Labour Force Survey } \\
\hline Note: D & STATIS $\mathrm{e}$ & & & & & & & & & & & \\
\hline
\end{tabular}


However, the scenario with regards to employment seems to be quite different. Unemployment rates for foreign-born population are much higher than that of the total population. Even among foreign born, unemployment rates are much higher for non-EU born population than that of EU born population. For example, in case of UK, $34 \%$ of total population has tertiary education, while $35 \%$ of foreign-born population has tertiary education. Among the foreign born, $31 \%$ of EU born are tertiary level educated, while the corresponding figure for non-EU born population is $37 \%$. Now, let's consider unemployment rates in UK in that year. $7 \%$ of the total population was unemployed, while $8 \%$ of foreign-born was unemployed in UK. Among the foreign -born, only $6 \%$ of EU born was unemployed, while the corresponding figure for non-EU born was as high as $10 \%$. So, there seem to be some other factors or combination of factors, other than education, at play for or against migrants in the EU, especially for those born outside EU.

\section{Conclusion}

One of the most prized benefits of geographic mobility arises from the following positive externality: larger labor markets lead to better skill matches. In turn, improved skill match translates into improved productivity. Greater geographic mobility will lead to regional labor-market adjustment and a better match between the demand and supply of skills. If geographic mobility improves the quality of job matches, individuals can make a higher return on their human capital. This increases incentives to invest in education.

\section{References:}

[1]. Rodríguez-Pose, Andrés; Tselios, Vassilis; Returns to migration, education and externalities in the European Union; Papers in Regional Science, Volume 89 Number 2 June 2010

[2]. Acemoglu D, Angrist J (2001) How large are human capital externalities? Evidence from compulsory schooling laws.NBER Macroeconomics Annual 2000 15: 9-59

[3]. Axelsson R, Westerlund O (1998) A panel study of migration, self-selection and household real income. Journal ofPopulation Economics 11: 113-126

[4]. Basu K, Narayan A, Ravallion M (2001) Is literacy shared within households? Theory and evidence for Bangladesh.Labour Economics 8: 649-665

[5]. Becker GS (1962) Investment in human capital: A theoretical analysis. Journal of Political Economy 70: 9-49

[6]. López-Bazo E, Vayá E, Artís M (2004) Regional externalities and growth: Evidence from European regions. Journal of Regional Science 44: 43-73

[7]. Mincer J (1974) Schooling, experience and earnings. National Bureau of Economic Research, New York

[8]. Mincer J (1978) Family migration decisions. Journal of Political Economy 86: 749-773

[9]. Rodríguez-Pose, Andrés; Vilalta-Bufí, Montserrat;Education, migration, and job satisfaction: The regional returns of human capital in the EU; Bruges European Economic Research Papers; BEER paper n ${ }^{\circ}$ 1, November 2004 